\title{
Simulation of small-scale waste biomass gasification integrated power production: a comparative performance analysis for timber and wood waste
}

\author{
Sahar Safarian, Runar Unnthorsson, Christiaan Richter \\ Faculty of Industrial Engineering, Mechanical Engineering and Computer Science, University of Iceland, Iceland
}

\begin{tabular}{l}
\hline \hline Article Info \\
\hline Article history: \\
Received Nov 25, 2019 \\
Revised Feb 19, 2020 \\
Accepted Mar 3, 2020
\end{tabular}

\section{Keywords:}

Electrical efficiency

Power production

Process simulation

Waste biomass gasification

Waste to energy

\begin{abstract}
A simulation model for integrated waste biomass gasification with cogeneration heat and power has been developed using Aspen Plus. The model can be used as a predictive tool for optimization of the gasifier performance. The system has been modeled in four stages. Firstly, moisture content of biomass is reduced. Secondly biomass is decomposed into its elements by specifying yield distribution. Then gasification reactions have been modeled using Gibbs free energy minimization approach. Finally, power is generated through the internal combustion engine as well as heat recovery system generator. In simulation study, the operating parameters like temperature, equivalence ratio (ER) and biomass moisture content are varied over wide range and their effect on syngas composition, low heating value (LHV) and electrical efficiency (EE) are investigated. Overally, increasing temperature and decreasing ER and MC lead to improvement of the gasification performance. However, for maximum electrical efficiency, it is important to find the optimal values of operating conditions. The optimum temperature, ER and $\mathrm{MC}$ of the down draft gasifier for timber and wood waste are $800^{\circ} \mathrm{C}$, 0.2-0.3 and 5\%. At such optimum conditions, $\mathrm{CO}$ and $\mathrm{H}_{2}$ reach to the highest production and LHV and $\mathrm{EE}$ are around 7.064 $\mathrm{MJ} \mathrm{Nm}^{-3}$ and $45 \%$, respectively.
\end{abstract}

This is an open access article under the CC BY-SA license.

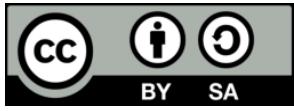

\section{Corresponding Author:}

Sahar Safarian,

Faculty of Industrial Engineering,

Mechanical Engineering and Computer Science,

University of Iceland,

Hjardarhagi 6, 107 Reykjavik, Iceland.

Email: sas79@hi.is

\section{INTRODUCTION}

The finite nature of conventional fossil fuels, increasing concerns due to environmental impact and health and safety considerations are encouraging to find renewable energy sources and alternative technologies to produce power $[1,2]$. In the last decades the interest in biomass has increased due to the growing attention to sustainable energy. Unlike fossil fuels that take so many years to be refilled, biomass can be regenerated relatively quickly and when it burns, carbon dioxide releases back to the atmosphere but this biogenic $\mathrm{CO}_{2}$ is not counted as a contributor to global warming [3-6].

Currently, biomass gasification integrated power production unit has been introduced as an efficient and environmentally friendly way for extracting energy from different organic wastes. Biomass gasification is a process of converting biomass fuel into syngas as a mixture of combustible gases through a sequence of thermo-chemical reactions. The produced gas through the biomass gasification can be conditioned to burn cleanly, like natural gas. This means a customer can install a gasifier system in an existing facility and reuse much of the same boiler, dryer, and ducting equipment [7-9]. 
Much important, waste gasification can be implemented as a more reliable energy supply technology for places which are far from the central energy networks and require district heat and power systems. Most of Iceland municipalities also contain several disparate towns/cities with the population lower than 10 thousand settlements [5]. Hence, in this paper, we study the potential of gasification for energy production for small communities in Iceland. Organic waste produced from household, industry and service sectors is an available option for biofuels production in Iceland. A general estimation shows that approximately $60 \%$ of the total waste is organic material which 43,41 and $16 \%$ of that are paper mixed, timber and wood and garden wastes [10]. Safarian et al. [11] found that among the various Icelandic waste biomass gasification systems, timber and wood waste is the most beneficial from the performance and environmental perspectives. The production of $1 \mathrm{kWh}$ electricity from timber through the gasification would lead to a global warming potential of $0.07 \mathrm{~kg} \mathrm{CO}$ eq, acidification potential of $0.09 \mathrm{~kg} \mathrm{SO}_{2 \mathrm{eq}}$, and eutrophication potential of $0.36 \mathrm{~kg} \mathrm{NO}_{3 \mathrm{eq}}$.

The primary aim of this work is to develop a steady state computer model for performance analysis of waste biomass gasifier integrated with CHP using Aspen Plus. The case study is in Iceland to assess power production from 1 ton of timber and wood waste as approximately most existing and greatest environmental beneficial biomass feed stock in this country. Finally, the effect of operating parameters like temperature, equivalence ratio (ER) and biomass moisture content (MC) on syngas composition, low heating value (LHV) and electrical efficiency (EE) are investigated to find the optimum conditions making highest LHV and electrical efficiency.

\section{MATERIAL AND METHODS}

An equilibrium simulation model has been developed for waste biomasses gasification integrated with CHP by using Aspen Plus. Penge Robinson equation of state with Boston-Mathias alpha function (PR-BM) was applied to calculate physical properties of the conventional components in the gasification process. HCOALGEN and DCOALIGT models were also employed for enthalpy and density of biomass and ash which are non-conventional components. MCINCPSD stream comprising three substreams of MIXED, CIPSD and NCPSD class, was also considered to define the biomass structure and ash streams which are not available in Aspen Plus component database [7]. The flow chart of the system simulated by using Aspen Plus is shown in Figure 1. The BIOMSS stream was defined as a nonconventional stream and it was created by specifying the elemental and gross compositions of feedstock obtained from proximate and elemental analyses given in Table 1 [11].

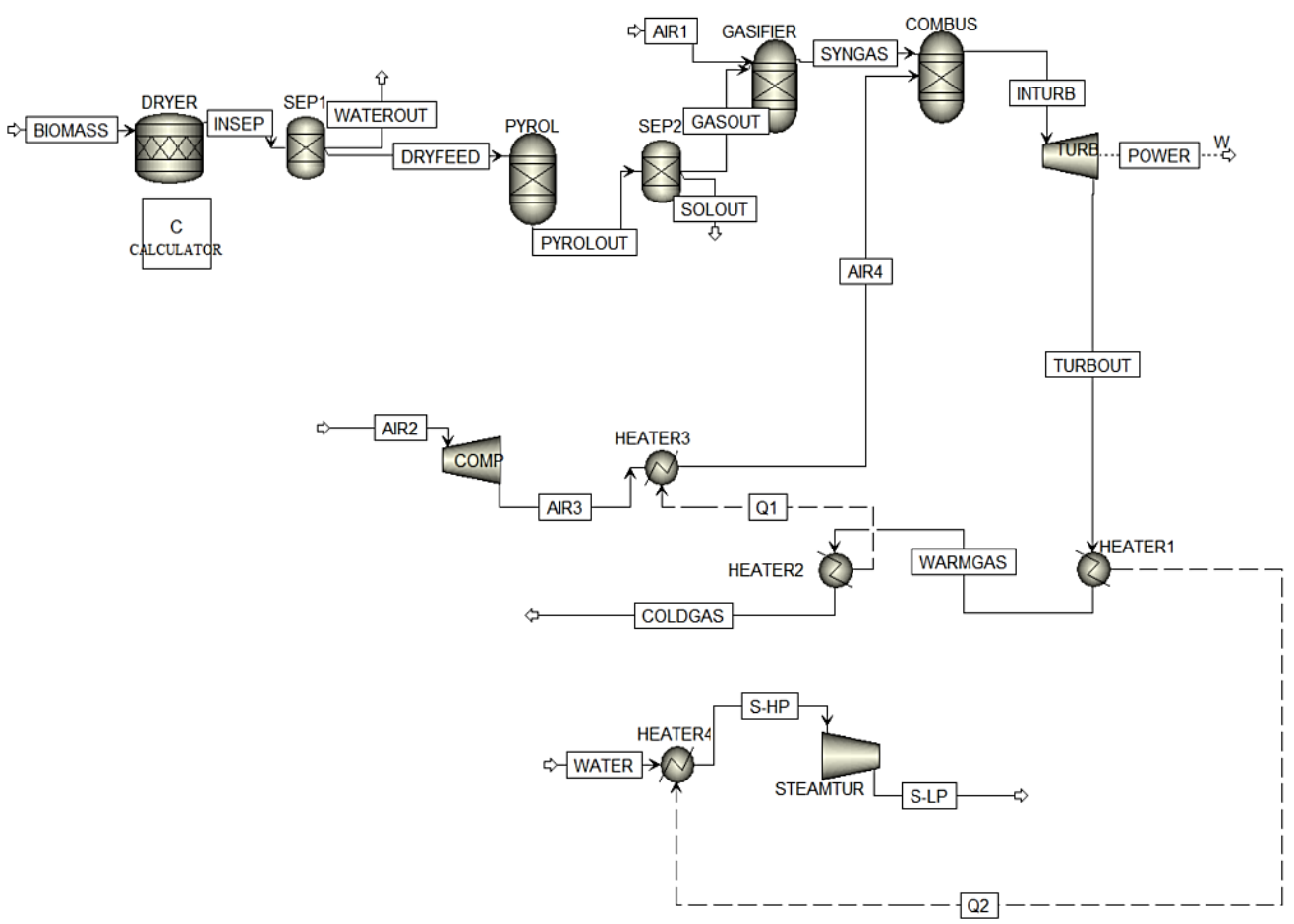

Figure 1. Flow chart of gasification simulation in Aspen Plus 
Table 1. Ultimate and proximate analysis of timber \& wood waste [11]

\begin{tabular}{lc}
\hline Proximate analysis & \\
\hline Proximate analysis (wt\%) & 5.01 \\
Moisture & 93.06 \\
Volatile matter (VM) & 6.38 \\
Fixed carbon (FC) & 0.56 \\
Ash & \\
Ultimate analysis & \\
Elemental analysis (wt\%- dry basis) & \\
C & 56.8 \\
H & 7.28 \\
N & 0.18 \\
Cl & 0.82 \\
S & 0.07 \\
O & 34.29 \\
\hline
\end{tabular}

Drying occurs at $100^{\circ} \mathrm{C}$ to achieve the moisture reduction to $5 \mathrm{wt} . \%$ of the original sample. This step is directed by the stoichiometric reactor RSTOIC in the Aspen Plus. This particular module is used to perform chemical reactions of known stoichiometry [12]. After drying, RYIELD, the yield reactor is brought to simulate the feed pyrolysis. In this step, the feedstock is converted to volatile materials (VM) and char. VM contains carbon, hydrogen, oxygen and nitrogen; Char is also converted into ash and carbon, by specifying the product distribution based on the proximate and ultimate analysis of the feedstock [7]. Then RGibbs is used to simulate the biomass gasification. The reactor calculates the syngas composition by minimizing the Gibbs free energy and assumes complete chemical equilibrium. The decomposed feed and air enter to the RGibbs reactor where partial oxidation and gasification reactions occur. Another RGibbs reactor is also simulated for combustion section with minimum air mixing. Principally, this process is also based on minimization of Gibbs free energy. The combustion chamber is followed by a gas turbine [13, 14]. The thermal content of the gas, obtained as the combustion heat is removed and consumed to convert water to high pressure steam though a HEATER. The generated steam finally drives a steam turbine and produces additional power $[15,16]$. The solid lines in the Figure 1 stand for the mass streams whereas the dashed lines are for the heat streams. The system is assumed to be auto-thermal so that a part of the biomass is combusted inside the gasifier in order to provide the heat required in situ. Heat is also provided by the hot product gas as well as the combustion chamber and utilized wherever needed.

\section{RESULTS AND DISCUSSION}

The developed model for waste biomass gasification is used to investigate the gasification performance of timber and wood waste. The effect of gasifier temperature, equivalence ration (ER) and moisture content (MC) on syngas composition, lower heating value (LHV) of produced gas and electrical efficiency (EE) are investigated. The lower heating value of product gas is calculated as [17, 18]:

$$
L H V_{\text {syngas }}\left(\mathrm{kj}^{\mathrm{N}} / \mathrm{Nm}^{3}\right)=4.2 \times\left(30 \times y_{\mathrm{CO}}+25.7 \times y_{\mathrm{H}_{2}}+85.4 \times y_{\mathrm{CH}_{4}}\right)
$$

where $\mathrm{y}$ is the mole fraction of gass pecies in the syngas (dry basis).

The main goal is finding optimal operating conditions to make the highest electrical efficiency. The electrical efficiency is the index of the power generated from the system compared to the original energy contained in the biomass feed and is defined by [12]:

$$
\eta_{\text {electrical }}=\frac{W_{\text {gas turbine }}+W_{\text {steam turbine }}-W_{\text {compressor }}}{M_{\text {biomass }} \times L H V_{\text {biomass }}}
$$

\subsection{Effect of temperature on system performance}

The effect of gasifier temperature on syngas mole fractions produced through the timber and wood waste gasification, is shown in Figure 2. Figure 3 also shows the LHV of syngas and the electrical efficiency of the gasifier system as a function of temperature. The sensitivity results in Figures 2 and 3 are studied at standard conditions of 1-ton input biomass, 0.25 air equivalence ratio and gasifier temperature in the window of $500-1500^{\circ} \mathrm{C}$

Based on Figure 2, the present carbon in the timber and wood waste is not used completely at low temperature $\left(500^{\circ} \mathrm{C}\right)$, so the syngas production could not be in an acceptable rate. At such a low temperature,

Simulation of small-scale waste biomass gasification integrated power production ... (Sahar Safarian) 
methane and unburned carbon will stand in syngas while by increasing temperature more carbon is oxidized and converted to carbon monoxide based on partial combustion reaction. Methane is also transferred into hydrogen by reverse methanation reaction. Water gas reaction also goes toward the production of both $\mathrm{CO}$ and $\mathrm{H}_{2}$ at high temperature. Hence, increasing the gasifier temperature favors hydrogen and carbon monoxide production, leads to the improvement of heating value of syngas as shown in Figure 3. However, at a specific temperature, yield of $\mathrm{H}_{2}$ and $\mathrm{CO}$ reach to an approximately constant values that this point is called the optimum gasifier temperature. The optimum operating temperature of the down draft gasifier for timber and wood waste is $800^{\circ} \mathrm{C}$. Methane production also decreases sharply at temperatures above $600^{\circ} \mathrm{C}$. LHV value for timber and wood waste at optimum temperature is about 7.054 $\mathrm{Mj} \mathrm{Nm}^{-3}$. Improving $\mathrm{LHV}$ of syngas leads to entering gases at high temperature to the gas turbine. Raising the turbine inlet temperature ameliorates output power from that as well as the steam turbine. It is because of that more steam is produced through the heat recovery from the hot flue gas. Electrical efficiency also increases in a gradual way near the optimum temperature, it reaches about $45 \%$ around $800^{\circ} \mathrm{C}$.



Figure 2. Effect of temperature on syngas mole fraction (dry basis, ER: 0.25 )

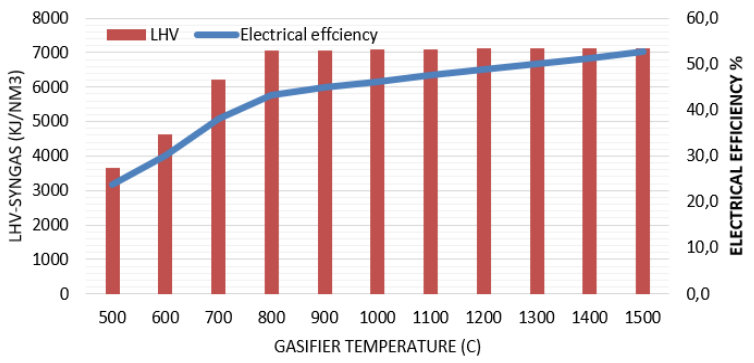

Figure 3. Effect of temperature on syngas LHV and electrical efficiency (ER: 0.25)

\subsection{Effect of ER on system performance}

Equivalence ratio (ER) as the ratio of the actual air value supplied to the gasifier to the stoichiometric air is a significant factor for showing the role of oxidizing agent. At low ER, biomass reactions will approach to the pyrolysis, however at higher values of ER the excess amount of oxygen is combusted which leads to the declining of syngas production. Hence, it is important to find the appropriate range of ER for biomass gasification that is investigated in our work. For timber and wood waste gasification, ER is varied from 0.2-0.65 and its influence on the syngas compositions is shown in Figure 4. The $\mathrm{H}_{2}$ and $\mathrm{CO}$ mole fractions decrease with increasing ER but an opposite trend for $\mathrm{CO}_{2}$ is exhibited. This is due to when ER rises, more oxygen is supplied for biomass reactions, so fuel goes toward the full combustion. The optimum ER lies between 0.2-0.3, till mole fractions of $\mathrm{CO}$ and $\mathrm{H}_{2}$ are higher than $25 \%$. By increasing ER, the heating value of the syngas and electrical efficiency also decrease as shown in Figure 5. As a whole, the LHV of the product gas and electrical efficiency depend strongly on ER and ER is function of syngas compositions in (1). At optimum span of ER, LHV and electrical efficiency from timber and wood waste gasification are around $7.064 \mathrm{MJ} \mathrm{Nm}^{-3}$ and $45 \%$.

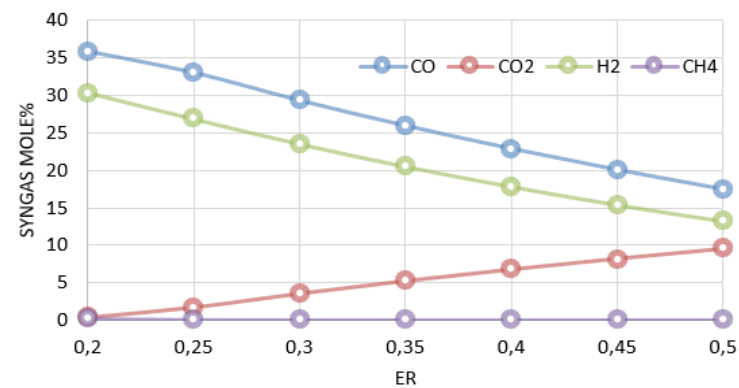

Figure 4. Effect of ER on syngas mole fraction (dry basis and gasifier temperature is $900^{\circ} \mathrm{C}$ )

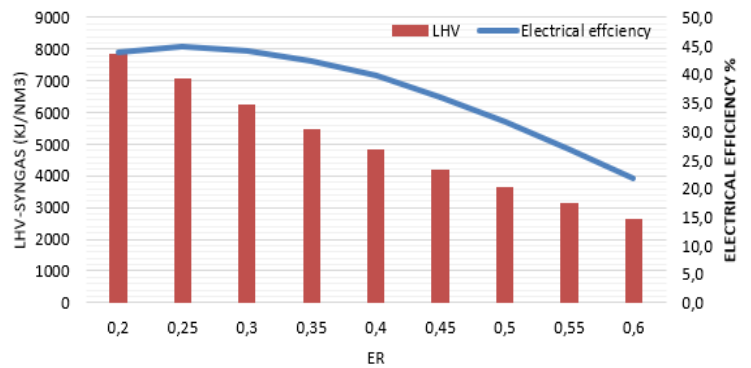

Figure 5. Effect of ER on syngas LHV and electrical efficiency (gasifier temperature is $900^{\circ} \mathrm{C}$ ) 


\subsection{Effect of MC on system performance}

The moisture content of the biomass is varied from 5 to $35 \%$ to investigate its effect on the performance of the gasifier integrated with CHP. Figure 6 shows the effect of biomass moisture content on syngas compositions. Moreover, impact of MC on syngas LHV and electrical efficiency of the system is depicted on Figure 7. Moisture content has a remarkable effect on gasifier performance. It is known that a high $\mathrm{MC}$ content is responsible for the reduction of $\mathrm{H}_{2}$ and $\mathrm{CO}$ in the produced gas and for the increase in $\mathrm{CO}_{2}$ mole fraction. As a consequence, the heating value of the syngas decreases while the MC increases. According to equilibrium mathematical method for downdraft gasifiers, the increase in biomass MC of 35\% results in the reduction of the LHV of the syngas by about $1.8 \mathrm{MJ} \mathrm{Nm}^{-3}$. Increasing moisture content also strongly degrades the system electrical efficiency. The increase in biomass $\mathrm{MC}$ of $35 \%$ results in the declining of the electrical efficiency by $32 \%$.

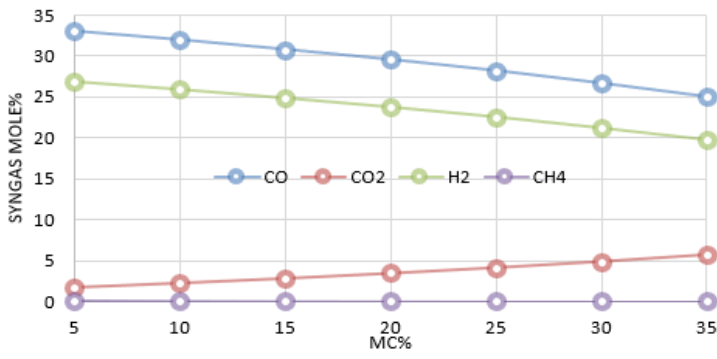

Figure 6. Effect of MC on syngas mole fraction (dry basis, gasifier temperature: $900^{\circ} \mathrm{C}$ and ER: $0.25)$

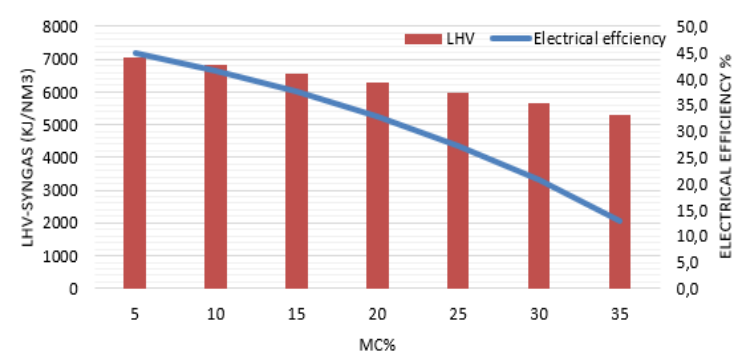

Figure 7. Effect of MC on syngas LHV and electrical efficiency (gasifier temperature: $900{ }^{\circ} \mathrm{C}$ and ER: 0.25)

\section{CONCLUSION}

A steady state equilibrium-based model was developed for waste biomass gasification using Aspen Plus simulator. The model was used for comparative analysis of the gasification performance of timber and wood waste in Iceland. In the model, sensitivity analysis was performed and the impact of varying gasifier temperature, ER and MC on syngas composition, LHV of syngas and electrical efficiency was investigated. Raise in temperature improves the gasifier performance, it increases the production of $\mathrm{CO}$ and $\mathrm{H}_{2}$ which leads to higher LHV and electrical efficiency. However, Increasing ER degrades the $\mathrm{CO}$ and $\mathrm{H}_{2}$ production which results in reduction of gasification performance. Moisture content has also a significant effect on gasifier performance. A high MC content is responsible for the reduction of $\mathrm{H}_{2}$ and $\mathrm{CO}$ in the product gas. Consequently, the increase in biomass $\mathrm{MC}$ of $35 \%$ results in the reduction of the LHV of the syngas and the system electrical efficiency by about $1.8 \mathrm{MJ} \mathrm{Nm}^{-3}$ and $32 \%$, respectively. The highest values of $\mathrm{CO}$ and $\mathrm{H}_{2}$ mole fraction, LHV and EE of the gasification system-based timber and wood waste located at $800^{\circ} \mathrm{C}$, $0.20-0.3$ of ER and 5\% of MC. In these conditions, LHV and electrical efficiency are around 7.064 $\mathrm{MJ} \mathrm{Nm}^{-3}$ and $45 \%$, respectively.

\section{ACKNOWLEDGEMENTS}

This paper was a part of the project funded by Icelandic Research Fund (IRF), (in Icelandic: Rannsoknasjodur) and the grant number is 196458-051.

\section{REFERENCES}

[1] S. Begum, M. Rasul and D. Akbar, "A numerical investigation of municipal solid waste gasification using aspen plus," Procedia engineering, vol. 90, pp. 710-717, 2014.

[2] S. Safarian, P. Khodaparast and M. Kateb, "Modeling and technical-economic optimization of electricity supply network by three photovoltaic systems," Journal of Solar Energy Engineering, vol. 136, no. 2, pp. 024501-1-024501-5, 2014.

[3] S. Safarian, S. Sattari and Z. Hamidzadeh, "Sustainability assessment of biodiesel supply chain from various biomasses and conversion technologies," BioPhysical Economics and Resource Quality, vol. 3, no. 2, 2018.

[4] S. Safarian, S. Sattari, R. Unnthorsson and Z. Hamidzadeh, "Prioritization of Bioethanol Production Systems from Agricultural and Waste Agricultural Biomass Using Multi-criteria Decision Making," Biophysical Economics and Resource Quality, vol. 4, no. 1, pp. 1-16, 2019. 
[5] S. Safarian and R. Unnthorsson, "An assessment of the sustainability of lignocellulosic bioethanol production from wastes in Iceland," Energies, vol. 11, no. 6, p. 1-16, 2018.

[6] T. L. T. Nguyen, J. E. Hermansen and R. G. Nielsen, "Environmental assessment of gasification technology for biomass conversion to energy in comparison with other alternatives: the case of wheat straw," Journal of cleaner production, vol. 53, pp. 138-148, 2013.

[7] S. Safarian, C. Richter and R. Unnthorsson, "Waste Biomass Gasification Simulation Using Aspen Plus: Performance Evaluation of Wood Chips, Sawdust and Mixed Paper Wastes," Journal of Power and Energy Engineering, vol. 7, no. 6, pp. 12-30, 2019.

[8] S. Safarian, R. Unnpórsson and C. Richter, "A review of biomass gasification modelling," Renewable and Sustainable Energy Reviews, vol. 110, pp. 378-391, 2019.

[9] S. Safarianbana, R. Unnthorsson and C. Richter, "Development of a New Stoichiometric Equilibrium-Based Model for Wood Chips and Mixed Paper Wastes Gasification by ASPEN Plus," in ASME 2019 International Mechanical Engineering Congress and Exposition: American Society of Mechanical Engineers Digital Collection, 2019.

[10] M. Sundberg, J. Guðmundsson and M. Guðmundsson, "Biofuel production in Iceland: survey of potential raw materials and yields to 2030," Mannvit Engineering, Reykjavik, 2010.

[11] S. Safarian, R. Unnthorsson and C. Richter, "Performance analysis and environmental assessment of small-scale waste biomass gasification integrated CHP in Iceland," Energy, vol. 197, 117268, 2020.

[12] T. Damartzis, S. Michailos and A. Zabaniotou, "Energetic assessment of a combined heat and power integrated biomass gasification-internal combustion engine system by using Aspen Plus ${ }^{\circledR}, "$ Fuel processing technology, vol. 95, pp. 37-44, 2012.

[13] S. Safarian and M. Bararzadeh, "Exergy analysis of high-performance cycles for gas turbine with air-bottoming," Journal of Mechanical Engineering Research, vol. 5, no. 2, pp. 38-49, 2012.

[14] S. Safarian, Y. Saboohi and M. Kateb, "Evaluation of energy recovery and potential of hydrogen production in Iranian natural gas transmission network," Energy policy, vol. 61, pp. 65-77, 2013.

[15] S. Safarian and M. Bararzadeh, "Exergy Recovery in Gas Pressure Compression Stations (GPCSs)," Gas Processing, vol. 3, no. 1, pp. 11-18, 2015.

[16] S. Safarian and M. Mousavi, "Improvement of Overall Efficiency in the Gas Transmission Networks: Employing Energy Recovery Systems," Gas Processing Journal, vol. 3, no. 2, pp. 1-24, 2015.

[17] P.-C. Kuo, W. Wu and W.-H. Chen, "Gasification performances of raw and torrefied biomass in a downdraft fixed bed gasifier using thermodynamic analysis," Fuel, vol. 117, pp. 1231-1241, 2014

[18] P. Lv, Z. Xiong, J. Chang, C. Wu, Y. Chen and J. Zhu, "An experimental study on biomass air-steam gasification in a fluidized bed," Bioresource technology, vol. 95, no. 1, pp. 95-101, 2004.

\section{BIOGRAPHIES OF AUTHORS}
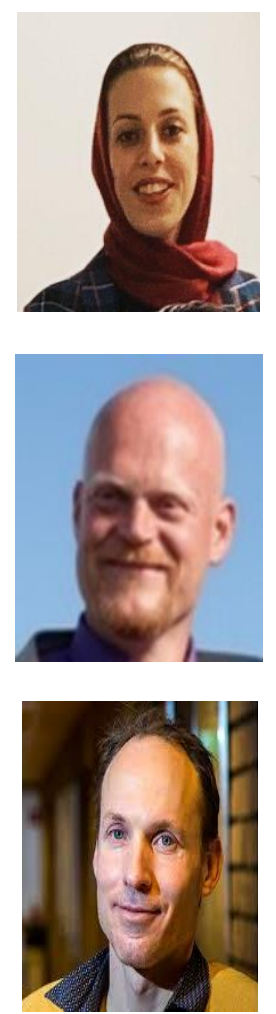

Sahar Safarian, graduated bachelor of chemical engineering and master in energy systems engineering. Currentlly, doing $\mathrm{PhD}$ on waste biomass gasification for energy production in University of Iceland. Main fields are simulation, performance analysis, techno-economic and environmental assessment, gasification integrated power generation and waste to power.

Runar Unnthorsson received the B.Sc., M.Sc., and Ph.D. degrees in mechanical engineering from University of Iceland. Now head of engineering faculty and head of biomass gasification group in Department of Industrial, Mechanical and Computer Engineering at University of Iceland. Areas of expertise are renewable energy, gasification integrated power generation technology, energy efficiency, performance engineering and etc.

Christiaan Richter received B. A. in mathematics and B.Sc. (Hons) in applied mathematics and education at University of Pretoria, South Africa. Graduated M.S. in chemical engineering and applied mathematics from University of Nebraska-Lincoln and $\mathrm{PhD}$ in chemical engineering from Northeastern University. Curentlly, he is professor in Faculty of Industrial Mechanical \& Computer Engineering at University of Iceland. Areas of expertise are electro-catalysis, electrochemical synthesis, biomass gasification, simulation and etc. 